\section{¿Cuánto vale (aún) la palabra del médico en la práctica clínica?}

\section{How respected is the physician's word, nowadays?}

\section{Sr. Editor:}

Una mujer de 59 años ingresó al Servicio de Urgencia del Hospital Naval de Viña del Mar, trasladada desde una clínica. Tenía una historia de 2 meses de evolución con pérdida ponderal de 12 kilos. Tres semanas antes de su ingreso inició dolor lumbar que le impidió su actividad laboral, cinco días antes comenzó con vómitos profusos $\mathrm{y}$ disnea progresiva.

En el examen físico de ingreso se comprobó una masa dura, de $5 \mathrm{~cm}$, en la mama derecha y varios ganglios en la región supraclavicular derecha. Estaba conciente, lúcida, con algo de apremio respiratorio y pálida. Exámenes de imágenes demostraron múltiples lesiones óseas e invasión tumoral del canal raquídeo a nivel L4-L5. Una TAC de tórax fue compatible con linfangitis carcinomatosa.

La calcemia de ingreso fue de $16 \mathrm{mg} / \mathrm{dl}$, por lo que recibió bifosfonato (Zometa (R)) e hidratación con solución salina isotónica. Recibió antieméticos y analgesia, con lo que se logró estabilizar. La calcemia se normalizó rápidamente.

Cuarenta y ocho horas después la paciente estaba tranquila, sin dolores ni vómitos. Afable y sonriente. Comencé a explicarle, sin entrar en detalles, de lo que parecía obvio que tenía pero me pidió por favor que esperásemos hasta recibir el informe de la biopsia de mama. Quería discutir el caso conmigo, estando presente su hija.

La biopsia concluyó en un carcinoma ductal infiltrante de la mama, moderadamente diferenciado. Todas las adenopatías estaban infiltradas por el carcinoma.

Con el diagnóstico confirmado expresé a la paciente la necesidad de explicarle su enfermedad y su tratamiento futuro. Me pidió con toda delicadeza que quería esperar la visita de su hija para tener la conversación. Entre tanto, el equipo oncológico urgía por la instalación de un reservorio para iniciar quimioterapia.

En la tarde de ese día, curiosamente soleado y claro para un día de invierno, nos juntamos los tres. La hija, joven arquitecto de 34 años, aparecía tranquila y demostraba gran afecto por su madre.
Sus dos hijas esperaron en la sala anexa.

Luego de explicarle en detalle la enfermedad, el tratamiento y posible pronóstico, la paciente, totalmente competente y tranquila, me expresó que no deseaba ningún otro tratamiento que analgesia para eventuales dolores. No expresó angustia, no hubo llanto, ni apremio. Irradiaba una paz interior notable. Le pregunté el motivo de su decisión y madre e hija contaron que el marido de la paciente había fallecido 2 años antes, por un cáncer tratado con quimioterapia y había presentado múltiples complicaciones, el 90\% del tiempo lo había pasado en el hospital y no había tenido tiempo para estar con su familia, al menos unas semanas, en condiciones estables.

Pese a nuevas recomendaciones de recibir quimioterapia, la paciente me agradeció "las buenas intenciones", pero me rogó que respetara su decisión.

Ante esta postura le expresé que mi obligación era respetar sus deseos y que el médico muchas veces tenía que "hacer cosas" pero también en otras tenía que abstenerse.

Sellamos los tres un pacto e inicié terapia esteroidal, que la alivió prontamente. Pudo dormir y comer bien y no tenía dolores.

Escribí en la ficha clínica la decisión y los motivos de la paciente para rechazar la quimioterapia y quedé tranquilo. Sin embargo, el grupo oncológico concluyó que la paciente tenía que recibir un "tratamiento científico" para evitar situaciones médicas catastróficas. En un principio obvié estos comentarios pero luego consulté a dos queridos amigos internistas y uno de ellos me dijo que "como estaban las cosas" debería pedirle a la paciente que escribiera su desestimiento en la ficha. Y cometí algo que nunca había hecho en mi práctica médica de 40 años: con gran pena y pidiéndole perdón, le solicité a mi paciente que pusiera por escrito en la ficha que desistía de la quimioterapia. Lo hizo en forma muy afable y sin discusión. Su hija también firmó, prontamente, como testigo.

Hasta el día de hoy quedé con la conciencia intranquila de haber "abusado" de mi paciente por este hecho. Creo que mi decisión fue comandada en parte por una conferencia escuchada días antes, en la cual un abogado "defensor de los médicos" dijo en parte de su discurso que la mejor defensa de un médico frente a una supuesta falta o negligencia era la mayor cantidad de exámenes e imágenes que 
se podían aportar. La evolución médica, la racionalidad de la terapéutica, la discusiones éticas y el respeto a los pacientes eran "cosas de poco valor frente al juez".

Este caso clínico me ha hecho meditar sobre los siguientes aspectos del accionar médico:

La palabra del médico, al menos en Chile, es cada vez menos "creíble y confiable". Para ser aceptada se necesita de testigos que avalen lo dicho. Lo que no está escrito carece de valor, especialmente frente a una situación judicial. Ello, a mi parecer, violenta la relación médico-paciente, especialmente en casos clínicos difíciles en que el paciente toma decisiones con su médico tratante que tienen una importancia vital.

Existe una agresividad en la actuación médica, en que se cree que mientras más cosas se hagan por el enfermo mejor será. Ello muchas veces no tiene racionalidad y existe el peligro de no respetar los deseos de los pacientes. Si bien es cierto que más procedimientos y exámenes pueden mejorar y aliviar a nuestros enfermos, también existe evidencia de lo contrario. Los riesgos de los procedimientos y tratamientos pueden acelerar la muerte en algunos casos. Muchas veces y frente a una misma enfermedad, el tratamiento del dolor y el apoyo al paciente puede alargar la sobrevida. Podría ser el caso de la paciente de mi relato.

Estoy muy de acuerdo con que al final de la vida, a veces lo menos es más y que es mucho más difícil en medicina hacer "poco o nada" que implementar una vasta actividad diagnóstica y terapéutica.

Cuatro meses después del alta tuve el privilegio de tenerla nuevamente como paciente intrahospi- talaria. Esta vez por una pielonefritis aguda, que cedió rápidamente, sin secuelas.

Me relató que en estos meses había sido feliz en su casa, con su hija y nietas. Salía al jardín en una silla de ruedas que le habían obsequiado sus compañeros de trabajo. Había mejorado mucho el apetito y ganado peso. No tenía dolores ni disnea. Daba algunos pasos sin problemas. Mantenía siempre una sonrisa y placidez de espíritu inimaginables. Fue muy generosa y amable en contar delante de mis Becados de Medicina Interna la buena calidad de vida que había tenido durante los últimos meses.

Esto enseña -dije a los Becados- que desconocemos aún muchos misterios del ser humano y que la ultratecnología y terapias avanzadas y nuevas no son siempre la solución a los problemas de nuestros enfermos. La fuerza del espíritu y los designios de Dios (para los creyentes) pueden ser muy poderosos. Es de esperar que no se pierda en nuestro futuro, en especial en Medicina Interna, el valor de la palabra, el cumplimiento de compromisos y el respeto a la decisión de nuestros pacientes.

Dr. Jaime Duclos H. Profesor de Medicina Universidad de Valparaíso. Servicio de Medicina, Hospital Naval "Almirante Nef". Viña del Mar. Chile.

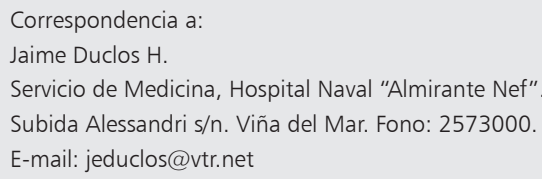

